$\xi=-1$

\title{
The Emerging Roles of Information Management in Government Agencies
}

\author{
*Norsyafiqah Filzah Mohamad Saodi, Muhammad Sharis Ikhwan Idris, Noradilah Aiza Saharuddin, Saiful Farik \\ Mat Yatin, Norhayati Hussin, Azmi Ab Rahman \\ ${ }^{I}$ Faculty of Information Management, Universiti Teknologi MARA (UiTM), Selangor, Malaysia \\ *Corresponding author: * Norsyafiqah Filzah Mohamad Saodi: Faculty of Information Management, Universiti Teknologi MARA \\ (UiTM), Selangor, Malaysia \\ E-mail: syafiqahfilzah.saodi@gmail.com
}

\begin{abstract}
Public ICT Strategic Plan or knowingly known as "Pelan Strategik ICT Sektor Awam (PSICTSA) 2016-2020 has been created to uphold the successful implementation of National Transformation Programme with regards of increasing system delivery among public agency as well as produce high-impact services and conducive ambience, eventually resulting to effective and efficient ICT delivery system. In short, the government has put a huge effort to ensure this ICT Strategic Plan will aid public sector to keeping up with sophisticated system at the same time improve the reputation of public delivery system within the government agency. Hence, government has highlight several guidelines for the implementation of PSICTSA, a set of elements that uphold the Government mission in striving Vision 2020 in line with the full leverage of information technology. As a result, well-developed and comprehensive strategic plan within public sector reflect high generate business total income and consistent revenue through ICT exploitation. Eventually, all these conveniences will assist the public sector's staffs to work in high resourceful manner at the same time brings thousands of benefits towards them in performing the daily tasks. Therefore, the purpose of this paper is to highlights the strategy of transforming the ICT division to Information Management Division within Public sector either ministry level or government agencies in Malaysia. An oral interview session has been conducted in one of the government agencies to collect and gather supportive information. The study shows that Public ICT strategic plan is essential component which reflects a clear visions for organization's future and established a set of goals advocate to improve organization as well achieve a quality shared vision. Ideally, the result drives the organizational to become a high-competitive company and improving the performance of overall personnel.
\end{abstract}

Keywords: Information Management Division, Strategic Information Management, Strategic Information Technology Plan, Government Modernization, e-government

\section{Introduction}

Information Technology (IT) has evolved from a support function to a critical resource for competitive strategy for number of firms. Historically information technology plays the vital role as supporting mechanism and not a strategic resource. In other words, IT or ICT can be a central hub for communication, inventory management, data management, management of information systems as well customer relationship management. In this information age, with rapid growth of ICT advancements, innovation and the business opportunities it creates tend to be technology based. In 2017, Malaysians celebrate 60 years as an independent nation. From the humble and uncertain beginnings, Malaysia have grown and evolved significantly into a modern economy and society.

Beginning with the era of the New Economic Policy (19711990), Malaysia stepped into the 2020 era (1991-2020). Vision 2020 is the ultimate goal of Malaysia to Transformation Agenda. Now, Malaysia have to be ready to face the next 30 years. The world in 2050 will be much different from the world today. Next vision of Malaysia is Transformasi Nasional (National Transformation) 2050' or TN50 which is an initiative to plan for the future of Malaysia in the period 2020 to 2050. From the vision of becoming a developed nation, Malaysia should strive to be amongst the top countries in the world in economic development, citizen well-being and innovation. The development of 1Malaysia obviously can be seen through the implementation Gagasan 1Malaysia: Rakyat Didahulukan Pencapaian Diutamakan (People First, Performance Now), Program Transformasi Ekonomi (Economic Transformation Program) as well as Model Baru Ekonomi (New Economic Model). This consistent effort from the government to grow Malaysia in line with The Eleventh Malaysia Plan, 2016-2020 (RMKe-11) with the theme of Pertumbuhan Berpaksikan Rakyat (Anchoring growth on people), which includes the new dimension to drive the path of well strategic management among the nation.

One of the key elements of RMKe-11 focus on the enhancement given to increase the productivity and efficiency in delivery system according to user's need and want. The significance of Information, Communication and Technology (ICT) targeting upon the economics growth achievement throughout the effective knowledge management as well as proper approach towards creativity and innovation. 


\section{Method}

This study primarily focuses on searching information related to the fact of public ICT strategy plan by conducting through interview. This method obviously provide the details of the overall process includes the before and after the existence of strategic plan and allow a richer appreciation of the process by which Public ICT strategic plan emerges and develop in public sector.

\section{Discussion}

Indeed, Information technology firm has become a part of vital and integral part of every business plan [1]. Hence, every organization have to drive their management as well as subordinates to be technology literates in order to be equal with the market technology potential at the same time with market changes that include user needs, new patterns of technology, emerging problems at the same time providing solution as well as with other possible opportunity [2].

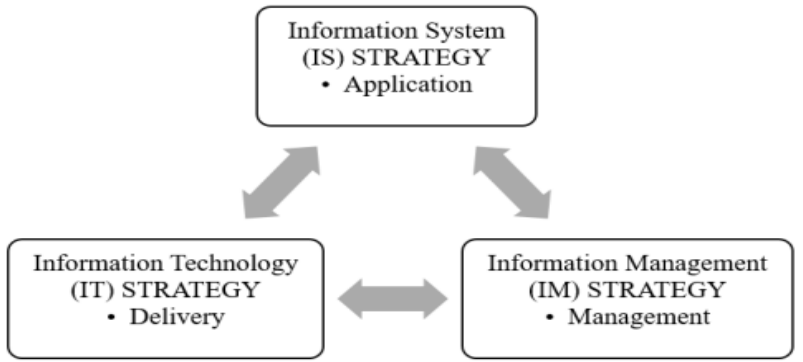

Fig. 1. Information Strategy Levels and Relationship

Figure 1 highlights three important areas that need to put extra concern in each organization with regards to Information System Strategy, Information Technology Strategy and Information Management Strategy [3]. In short, these three linkages must be worked together to achieve the desire goals. Information Managements can connect to management, which is organizationbased, relationship oriented and management focused. This area is most significance in organization as it acts as main driver in moving both systems and technology that include information policy, vision, relationship between IM, IS and ICT.

While for Information Systems are the division of unit based, demand oriented and business focused. On top of that, it is also can be a set of computer-based and organization-based procedures which transforming data into information. Apart from that, information systems allow the human to come out with a decision, as there will provide desired data or information accordingly through a process called system and process. Normally, this Information System will be implement in most of the department like Human Resources, Finance, Procurement and etc. In short, information system plays the crucial role in organization due to application and systems setup. Finally, Information Technology (IT) or Information and Communication Technology (ICT) focusing on activity-based, supply-oriented and technology focused. Throughout this area, it has various components for instances computers, microprocessors, telecommunications as well as office automation.

Hence, IT or ICT can be as method, techniques and tools used to uphold the process of accessing, storage, retrieval, use and sharing information. In conclusion, IT or ICT can represent as both hardware and software.

\section{Restructuring ICT Division to Information Management Division}

The strategy on restructuring ICT Division to Information Management Division in government agency gives the multi-perspectives and views of change. This change is referring to the transformation of technology to information and knowledge age. The change is brought about by many factors which are people, structure and politics. Many efforts have been made aiming to encourage the government agencies to boost the economic growth in Malaysia. However, in managing ICT is not going to be made easier with all the changes taking place, either because of technology or non-technology factors. A strategic plan for new agenda and activities should be done for an organization in government agency to change in long term duration. With this change, managing ICT will succeed if leaders are able to manage the change in technology, processes, management, skills and roles of people's. Other than that, leaders are also needed to deal effectively with solving crisis or problems due to ICT. On top of that, they have to ensure the strategic plan should be implementing and adapting in order to maintain stability and improvement internally. The restructuring organization is a concept that means organizational re-design, people transformation, as well as process orientation. With respect to all the above, there are several issues arise on implementing strategic plan yet still able to cater successful implementation in government agencies.

MAMPU (Malaysian Administrative Modernization and Management Planning Unit) Strategic Plan 2016-2020, has highlighted several guidelines where MAMPU will be the main driver of sophisticated administration and management for public services. Secondly is being a planner as well as an expert of ICT and information management areas in each organization during the initial phase. MAMPU ought to expand more research and development of delivering best and succeed ICT and information management services. In short, MAMPU is one the gigantic organizations that need to play their role in making sure the National Transformation succeed in line with Vision 2020. Based on Ministry of Communication and Multimedia Malaysia, Information Management Division acts as a strategic leader in the implementation of ICT programs for the ministry and its departments or agencies. The functions of the ICT departments are being discussed as follows:

1) To develop, coordinate and monitor implementation of the ICT strategic plan and assess the impact of ICT programs in the ministry and its departments or agencies.

2) To ensure the planning and implementation of ICT programs of the ministry and its departments/agencies are in accordance with the direction of ICT development in the public sector.

3) To strengthen ICT policies and organizational structure to achieve effectiveness and efficiency of ICT services; and others [4].

4) Table 1 and Table 2 below is the list of Malaysian ministries and government agencies that undergone transformation of ICT Division to Information Management Division. Out of 26 Ministries, 13 ministries have already undergone the transformation process.

Table 1. List of Malaysian ministries that undergone transformation of ICT Division to Information Management Division.

\section{MINISTRY LEVEL}

1. Ministry of Agriculture (Kementerian Pertanian dan Industri Asas Tani)

2. Ministry of Communication and Commission (Kementerian Komunikasi dan Multimedia Malaysia)

3. Ministry of Education (Kementerian Pendidikan Malaysia)

4. Ministry of Energy, Green Technology and Water (Kementerian Tenaga, Teknologi Hijau dan Air)

5. Ministry of Federal Territories (Kementerian Wilayah Persekutuan Malaysia)

6. Ministry of Health (Kementerian Kesihatan Malaysia)

7. Ministry of Human Resource Malaysia (Kementerian Sumber Manusia Malaysia)

8. Ministry of International Trade and Industries (Kementerian Perdagangan Antarabangsa dan Industri)

9. Ministry of Natural Resources and Environment (Kementerian Sumber Asli dan Alam Sekitar Malaysia)

10. Ministry of Plantation, Industries and Commodities (Kementerian Perusahaan, Perladangan dan Komoditi)

11. Ministry of Tourism and Culture Malaysia (Kementerian Pelancongan dan Kebudayaan Malaysia)

12. Ministry of Transport Malaysia (Kementerian Pengangkutan Malaysia)

13. Ministry of Women, Family and Community Development (Kementerian Pembangunan Wanita, Keluarga dan Masyarakat Ma- 
laysia)

Table 2. List of Malaysian government agencies that undergone transformation of ICT Division to Information Management Division GOVERNMENT AGENCIES LEVEL

1. Construction Industry Development Board (Lembaga Pembangunan IndustriPembinaan)

2. Department of Irrigation and Drainage (Jabatan Pengairan dan Saliran)

3. Department of Islamic Development (Jabatan Kemajuan Islam)

4. Department of Social Welfare Malaysia (Jabatan Kebajikan Masyarakat Malaysia)

5. Department of Statistics (JabatannPerangkaan)

6. Education Service Commission (Suruhanjaya Perkhidmatan Pendidikan)

7. Federal Territories Development and Klang Valley Planning Division (Bahagian Kemajuan Wilayah Persekutuan dan Perancangan Lembah Klang)

8. Fisheries Development Authority of Malaysian (Lembaga Kemajuan Ikan Malaysia)

9. Intellectual Property Corporation of Malaysia (Perbadanan Harta Intelek Malaysia)

10. Kuala Lumpur City Hall (Dewan Bandaraya Kuala Lumpur)

11. Legal Affairs Division (Bahagian Hal EhwalUndang-Undang)

12. Malaysia Co-operative Societies Commission (Suruhanjaya Koperasi Malaysia)

13. Malaysian Agricultural Research and Development Institute (Institut Penyelidikan dan Kemajuan Pertanian Malaysia)

14. Malaysian Nuclear Agency (Agensi Nuklear Malaysia)

15. Public Works Department (Jabatan Kerja Raya Malaysia)

Out of 152 government agencies, 15 have already undergone the transformation. It is understood that the best prescription to restructure its entirety involvement within the government agencies.

According to Malcom (1989) as cited in Raja Malik Mohamed, [5] there are several key characteristics of successful strategy approaches to information management which is:

- Thinking towards change;

In the first thing, a lot of view is required as to why change is required, how change is to be managed and what stages of change implementation are essentials. It is believed that this thing has to be translated into a Restructure Blueprint before being further translated into planned action. However, it should be remembered that without creates the plan, the higher failure risk and potential inability to succeed. Basically, these have to be the role of the leaders and top echelons in the organization.

- $\quad$ Strong leadership;

As a basic rule, changes will start with the leadership and followed by acceptance by the organizational citizen. In this order, the top management must play the role of transformational leaders with providing necessary policy and standard, organization structure, ensuring that ICT personnel have sufficient authority, influence and resource, and all personnel are given enough enticement and motivation.

\section{- Smart partnership;}

Organizational citizens must be educated in preparing for restructuring. Even more important, they should be made to expect that restructuring can happen anytime and continuously, and become a part of organizational survival. Personnel have to learn to expect that anything can happen, especially due to this strategy for restructuring of ICT division to information management division.

- Training and readiness for the unexpected.

Organization management also needs to address organizational issues like manpower and culture. At this point, organization needs to provide quality education and training to ensure sufficient and appropriate training to all players. Hence, several modules have been published out in order to support this transformation for instance; Web Development with Joomla Siri 1/2017, Kursus Metodologi Pembangunan Pelan Strategik ICT (ISP) Siri $1 / 2017$, and many more that been prepared by INTAN (National Institute of Public Administration) which is the public training center under the Public Service Department [2].

\section{Roles of ICT and Information Player}

The world is changing rapidly which it has been increasing by loops and bounds before long time and most of the organization consist of employee that can handle obstacles in their near future. Behind this growth, there is one department who plays the vital role called as" Information Technology (IT) or Information Communication Technology (ICT)", where most of the organization usually rely on in order to ensure the smooth sailing of their business and operation. The front liner of IT and ICT depends on Chief Information Officer (CIO), the head of information technology within an organization who has been charged with broaden of roles with different responsibilities in regards of operation and development of IT. Lawry, Waddel and Singh [6], highlighted that CIO (Chief Information Officer) roles and responsibilities in the public sector are fast evolving due to important role of ICT for government processes and electronic services [5]. The new and fast emerging CKO (Chief Knowledge Officer) is responsible for knowledge generation for example knowledge management activities such as knowledge creation, capture, access and application. CKO is involved in helping everyone in the organization to work smarter. In facilitating knowledge sharing among workers, he/she ensures the development of knowledge-based products and services through a knowledge platform. Today's platforms are in the form of computing facilities and technologies such as the Internet, Intranet and others. While Chief Digital Officer (CDO) is responsible not only focusing on the development of corporate digital strategies, ensuring the organization to keep up to date with the changes in technology and consumers' demands, hence the overall responsibility for corporate digital footprint. Their ultimate mission rely on to comprehend and stay in touch with customers and to take part in crafting the experience with those customers receive [7].

\section{Managing Future and Emerging Technologies}

Generally, government agency will often come to face various descriptions on the change in business, governance and economy that introduced by technology. Emerging and future technologies are technologies that are new, state-of-art and often disruptive, that re-shapes civilization, environment, institution and individual. Assesses technology paths into three which namely transformation, extension and niche technologies ${ }^{9}$. The author views on transformation technology as the revolution of the culture such as computer, for the extension technology as providing new scope and applications for example networks and cellular communication, and niche technology as special applications for example software programs or packages. Technology trends is a migrating from operational (technical-based) to tactical (systembased) to strategic (management-based). Johnson [8] has adequately summarized the new roles of ICT. He states that the way users exploit and benefit from technology surge has altered. He stressed that:

- Technology will be for everyone where it change the way of work and become sophisticated

- Abilities of technologies increase in multiplying effect

- Technology change governance and create businesses

- Technology drives management processes and practices [6]

In discussing on future technologies, there are issues and challenges on managing ICT that cannot be escaped. It is paramount significance for top management in government agency such as CIO to be conversant with technology because of the high cost incurred due to the need for infinitely networked equipment, as well as specialized skills and expertise. A technology surge is so rapid that it becomes a foremost issue of concern. However, top management must put extra concern on technology challenge for a better decision making. Besides, they have to ensure various measures in terms of their management skills and organizational readiness. The most important thing is every government agency need to have proper ICT strategic plan to ensure the aim is persistent on track. In short, strategic plan will be the main guideline 
for every organization in terms of way of ICT thinking, particularly with relations to information and knowledge.

\section{Conclusion}

This case study has discussed several key indicators in public ICT strategy plan that have undergone several changes which mostly to align ultimate public ICT objective. This change was deemed necessary in order to revised all the strategic plan of ICT and even ICT delivery for the sake of guaranteeing the quality of information and data that have been shared and utilized at the same time giving access to the public.
As we are in digital era, all the system that functioning to provide access to user ought to be enhance thoroughly. In addition, all of these changes must lies on the professional, where usually CIO will be hold the main responsibility. A successful CIO that develops and agile, forward thinking IT function, mastering the basics and focusing on customer inspired-innovation, is bench marked to be an influencer for the entire organization. The top management might as well to give cooperation to ensure the mission and vision that has been aimed should be accomplished. Consequently, the new birth of Information Management division will be fully established as one of the government conquest to preserve and protect the valuable assets in ICT or IT as well as the information in safe hands.

Table 3. List of three major of information player in organization

\begin{tabular}{|c|c|c|c|}
\hline Roles & $\begin{array}{c}\text { CIO } \\
\text { (Chief Information Officer) }\end{array}$ & $\begin{array}{c}\text { CKO } \\
\text { (Chief Knowledge Officer) }\end{array}$ & $\begin{array}{c}\text { CDO } \\
\text { (Chief Digital Officer) } \\
\end{array}$ \\
\hline $\begin{array}{l}\text { Task and } \\
\text { Responsibility }\end{array}$ & $\begin{array}{l}\text { Clearly understand of CEO's vision for } \\
\text { IT } \\
\text { CEO of the organization needs to share } \\
\text { their full vision for organization hence the } \\
\text { CIO will have the whole picture of the } \\
\text { strategic plan of organization. }\end{array}$ & $\begin{array}{l}\text { Develop well a good strategy of knowledge } \\
\text { wisely } \\
\text { Leads executive management to develop } \\
\text { an enterprise knowledge strategy; validates } \\
\text { this strategy across the enterprise, and ensures } \\
\text { that its evolution complements and inte- } \\
\text { grates with business strategy. }\end{array}$ & $\begin{array}{l}\text { Shift digital capabilities into strategic } \\
\text { priorities } \\
\text { Digital won't get the visibility or sup- } \\
\text { port its requirements if it is not helping } \\
\text { the company get where it wants to go. } \\
\text { Develop and administer the digital } \\
\text { project portfolio. }\end{array}$ \\
\hline $\begin{array}{l}\text { Roles in } \\
\text { Organization }\end{array}$ & $\begin{array}{l}\text { Recognize the ambiguity of CIO role } \\
\text { The CEO of organization need to identify } \\
\text { of the CIO role thus the CIO can perform } \\
\text { outstanding task and contribute endlessly } \\
\text { to the in organization. }\end{array}$ & $\begin{array}{l}\text { Develop tactical plants in Knowledge Strate- } \\
\text { gy } \\
\text { Oversees the development of tactical } \\
\text { plans to implement the knowledge strate- } \\
\text { gy, including which organizational units are } \\
\text { implemented and when, and the definition of } \\
\text { specific programs for harvesting, leveraging } \\
\text { and creating knowledge. }\end{array}$ & $\begin{array}{l}\text { Utilize the digital applications to } \\
\text { measure successfulness } \\
\text { Measure new efficiencies and Return on } \\
\text { Investment (ROI). Shifting manual } \\
\text { processes with technology drives lead to } \\
\text { cost savings and revenue generation. } \\
\text { The CDO's oversight across digital } \\
\text { initiatives positions him or her uniquely } \\
\text { well to measure success. }\end{array}$ \\
\hline $\begin{array}{l}\text { Delivery of } \\
\text { Services }\end{array}$ & $\begin{array}{l}\text { Provide service and solution commit- } \\
\text { ments } \\
\text { CIO is expected to deliver effective IT } \\
\text { services as well as able to lead the suc- } \\
\text { cessful implementation of IT projects. }\end{array}$ & $\begin{array}{l}\text { Strategy in managing top priority of daily } \\
\text { tasks. } \\
\text { Sets priorities and secures funding for } \\
\text { knowledge management }(\mathrm{KM}) \text { programs. }\end{array}$ & $\begin{array}{l}\text { Analyse the multi-function of digital } \\
\text { capabilities } \\
\text { Provide as executive sponsor for digital } \\
\text { process innovation. Other executives } \\
\text { might not be measured on new func- } \\
\text { tionality or economies of scale that } \\
\text { digital capabilities enable. }\end{array}$ \\
\hline $\begin{array}{l}\text { Build a rela- } \\
\text { tionship }\end{array}$ & $\begin{array}{l}\text { Form a strategy relationship } \\
\text { CIO ought to focus an attention on top } \\
\text { management in order to fulfil their basic } \\
\text { services. CIO need to fulfil most of CEO } \\
\text { expectation regarding of IT's environment } \\
\text { at the same time proactively seek relevant } \\
\text { information. }\end{array}$ & $\begin{array}{l}\text { Form a relationship between KM program } \\
\text { with the organizational structure } \\
\text { Oversees the building of the KM program and } \\
\text { the implementation of the enabling infra- } \\
\text { structure including designing and im- } \\
\text { plementing an organizational structure; } \\
\text { defining operating processes; specifying, } \\
\text { selecting and implementing technologies and } \\
\text { applications; and defining policies for } \\
\text { security, usage, maintenance by knowledge } \\
\text { owners and participation by user commu- } \\
\text { nities. }\end{array}$ & $\begin{array}{l}\text { Multifunction of skills and capabili- } \\
\text { ties } \\
\text { Become as "executive intermediary" } \\
\text { during delivery. This often means en- } \\
\text { listing involvement from other execu- } \\
\text { tives, re-establishing priorities, acting as } \\
\text { a good tutor, or serving as decider dur- } \\
\text { ing the rollout of digital capabilities. }\end{array}$ \\
\hline
\end{tabular}

\section{References}

[1] Gupta YP. The chief executive officer and the chief information officer: the strategic partnership. Journal of Information Technology. 1991; 6: 128-139. doi:10.1057/jit.1991.28

[2] Siegel D. Entrepreneurship and technological change. Cheltenhem: Edward Elgar Publishing; 2011

[3] Earl MJ. Management strategies for IT. London: Prentice Hall; 1989.

[4] The Malaysian public sector ICT strategic plan 2016 - 2020. (n.d.). Retrieved from http://www.mampu.gov.my/en/ict-strategicplan

[5] Raja Malik Mohamed. Challenges in managing information and communications technology: A CIO Guide. Kuala Lumpur: INTAN Management Series; 2003

[6] Lawry R, Waddel D \& Singh M. Roles, responsibilities and future of chief information officers (CIOs) in the public sector. Proceedings of European and Mediterranean conference on information systems 2007. Spain: Polytechnic University of Valencia; 2007.

[7] Dyche J. 6 responsibilities of the chief digital officer. In Business strategy and it innovation. Retrieved from http://www.cio.com/article/2997180/cio-role/6-responsibilities-ofthe-chief-digital-officer.html

[8] Johnson M. Managing in the next millennium. Boston: Butterworth-Heinemann; 1995. 